\title{
APLICAÇÃO DOS MÉTODOS ELETROMAGNÉTICOS INDUTIVO, ELETRORRESISTIVIDADE E IP DOMÍNIO DO TEMPO EM CARACTERIZAÇÃO GEOAMBIENTAL
}

\author{
Geórgia Castro de Souza \\ Orientador: Dr. Vagner Roberto Elis (IAG-USP) \\ 85 p. - Dissertação (Mestrado) - Defesa 20.08.2007
}

\begin{abstract}
RESUMO. Este projeto visa caracterizar o problema ambiental gerado na região do Lixão de Serrana, que se localiza na cidade de Ribeirão Preto, no estado de São Paulo. Neste local, devido à existência de uma grande cavidade no solo, originada da extração de areia para a construção civil, em meados da década de 1970 iniciou-se a disposição de resíduos domésticos, industriais e hospitalares. Hoje em dia, o lixão já se encontra saturado e sem atividade. No entanto, os danos causados pela disposição inadequada dos resíduos ainda estão presentes e a pluma de contaminação gerada ainda se desenvolve. A metodologia utilizada neste trabalho consiste na integração de técnicas geofísicas, as quais vêm se mostrando eficientes na avaliação e caracterização de problemas ambientais. 0 projeto tem como foco desenvolver a aplicação dos seguintes métodos de prospecção geofísica: eletrorresistividade, polarização induzida no domínio do tempo e eletromagnético indutivo, nos estudos de geotecnia e meio ambiente. 0 projeto baseou-se na compilação e reinterpretação de uma grande quantidade de dados geofísicos pré-existentes e alguns dados coletados durante o desenvolvimento do trabalho, associados a dados de geologia de superfície e de poços. Dessa forma, com a integração de informações, procurou-se estudar parâmetros para a avaliação dos problemas associados à contaminação de solos tropicais e águas subterrâneas por depósito de resíduos urbanos. 0 presente trabalho procurou atingir dois objetivos principais. 0 primeiro deles foi à aplicação e interpretação de ensaios geoelétricos para uma melhor caracterização geológica da área. Os dados geofísicos foram vinculados às informações geológicas de poços existentes para uma melhor interpretação e definição da geologia local. 0 segundo foi a caracterização do problema ambiental, utilizando os métodos geofísicos e algumas análises químicas de água, disponibilizadas pela Prefeitura de Ribeirão Preto. Dentro de tal contexto, procurou-se estudar, também o comportamento dos parâmetros geofísicos como cargabilidade e constante de tempo na delimitação das cavas preenchidas com resíduos, a zona saturada em chorume próxima a esses e da pluma de contaminação dentro da zona saturada (zona profunda), uma vez que as respostas aos dois parâmetros acima mencionados, o que não ocorre com a resistividade (e condutividade) cujas respostas vêm sendo mais estudadas. A utilização dos resultados obtidos por sondagens elétricas interpretadas com base em informações de poços de monitoramento de água e de coleta de chorume, poços tubulares profundos, sondagens a trado e de geologia de superfície possibilitou um melhor conhecimento da geologia da área do depósito, que apresenta relações de contato complexas entre as 3 (três) unidades geológicas diferentes (colúvio, basalto e arenito) e 2 (dois) tipos de aqüíferos. A partir do estabelecimento do modelo geológico, pôde-se utilizar os resultados de caminhamentos elétricos (resistividade e polarização induzida) para entender as relações entre os resíduos e o meio natural nos limites do lixão. Os resultados dos perfis eletromagnéticos possibilitaram uma visualização do impacto ambiental na área do depósito e seu entorno imediato, bem como 0 estabelecimento de hipóteses sobre o formato e o caminho da pluma de contaminação, cuja existência na área fora constatada pelos dados de análises químicas das águas subterrâneas.
\end{abstract}

ABSTRACT. This project aims characterizing environmental problem generated in Serrana Landfill region, contained in Ribeirão Preto city (SP). In there, due to a huge soil cavity originated from sand extraction used in building site, the disposal of domestic, industrial and hospital residues started in mid 1970s. Nowadays, this landfill is saturated and without activity. However, damages caused by the inadequate residue disposition are still present, and the generated contamination plume still remains. The methodology used in this work consists in the integration of geophysical techniques efficient in the evaluation and characterization of environmental problems. The focus in here is to apply geophysical prospecting methods, such as resistivity, induced polarization related to time domains as well as electromagnetic inductive method, in geotechnical and environmental studies. The project was based on a compilation and reinterpretation of a large amount of pre-existent geophysical data as well as those collected during work conduction associated to surface geology and well data. In such way, with integrated information it attempted to study parameters to evaluate problems associated to tropical soil and groundwater contamination for urban residue landfill. This project accomplishment intends to achieve two main objectives. First of all it was application and interpretation of geoelectrical assays to a better geological characterization from the area. Geophysical data were linked to geological information from existent wells for a better local geology interpretation and definition. The second objective was the environmental problem characterization by using geophysical method and some water chemical analysis available by Ribeirão Preto City hall. In this context, it was also studied a geophysical parameter behavior of chargeability and time constant in digging delimitation filled out with residues from leachate shallow area and contamination plume inside of saturated area (deep area), once two mentioned parameter answers are not well known. This unknowing answer never happens with resistivity (and conductivity) case. The use of results obtained from electrical sounding has interpreted base on information about water monitoring wells and leachate collection, deep tubular wells, auger sounding, and surface geology made possible a better knowledge about landfill geology, which presents complex contact among three different geological units, and two types of aquifer. Since geological model establishment, results of electric profiling (resistivity and induced polarization) can be used in order to understand the association between residues and environment in landfill limits. Results of electromagnetic profile make possible a visualization of environmental impact in landfill zone and its surrounding as well as the establishment of hypothesis about format and way of contamination plume whose existence in the zone is verified by data from groundwater chemical analysis. 